Journal of

Philosophy, Culture and

Religion

(JPCR)

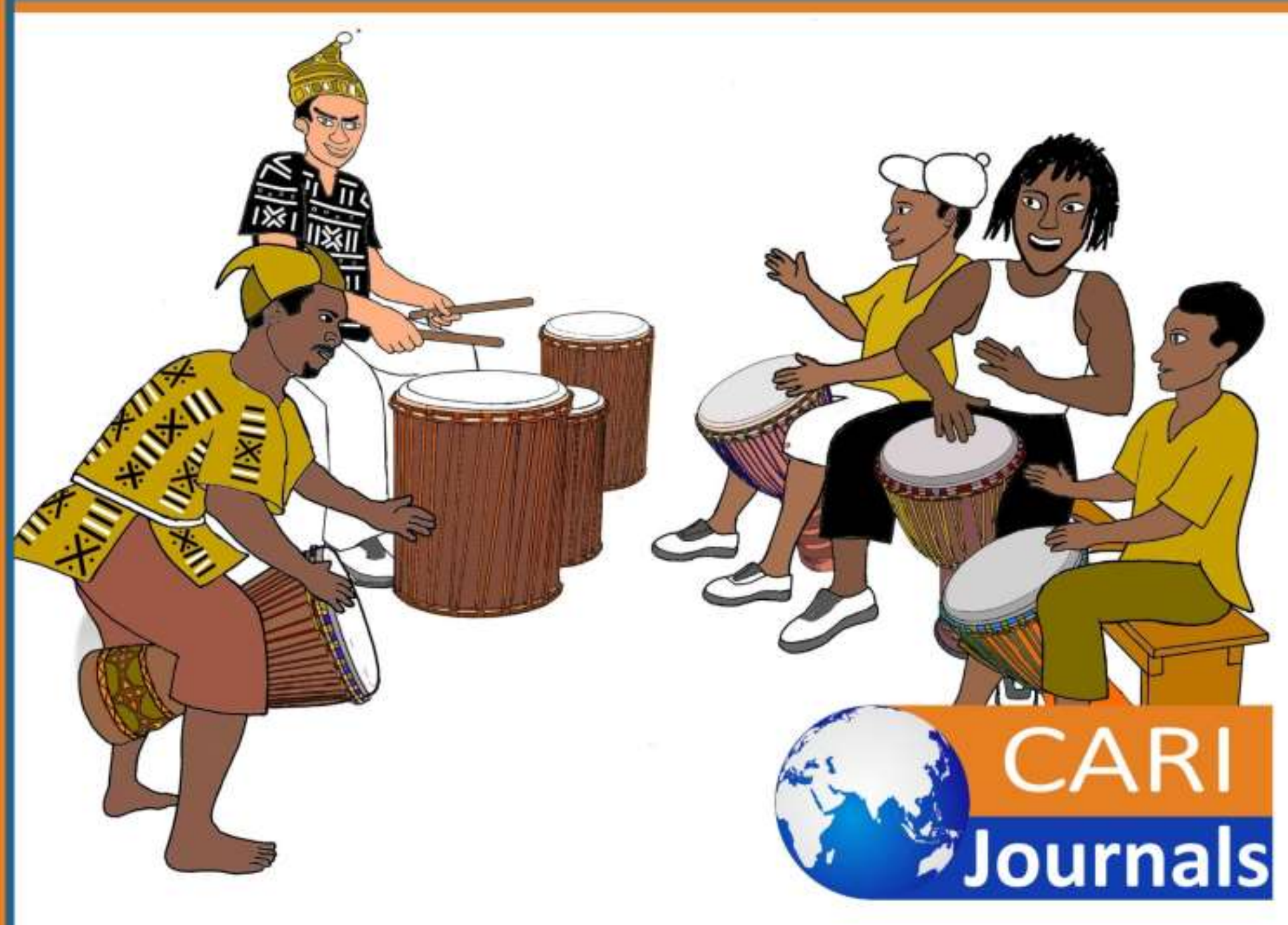




\title{
Factors Influencing Vocation to Brotherhood in Holy Cross Congregation District of East Africa
}

\author{
${ }^{1 *}$ Kakeeto Rogers \\ ${ }^{1}$ Institute of Spirituality and Religious Formation, Catholic University of Eastern Africa, \\ Nairobi, Kenya \\ *Corresponding Author's Email: kax200@yahoo.co.uk \\ ${ }^{2}$ Dr. Fredrick Omollo \\ Institute of Spirituality and Religious Formation, Catholic University of Eastern Africa, \\ Nairobi, Kenya \\ ${ }^{3}$ Dr. Remigius Ikpe \\ Institute of Spirituality and Religious Formation, Catholic University of Eastern Africa, \\ Nairobi, Kenya
}

\begin{abstract}
Purpose: The general objective of the study is to assess the factors influencing the rate of vocation to be a brother in Holy Cross Congregation in East Africa. The objectives that guided the study are; to explore how social status influence vocation to be a brother; to examine how the factor of being a clerical congregation may be influencing vocation to a brother; to determine how the need for professional career satisfaction influences vocation to be a brother, to investigate how different motivations influences vocation to be a brother and to identify possible ways of responding to challenges of vocation to be a brother in Holy Cross Congregation in East Africa.
\end{abstract}

Methodology: The study used convergent parallel approach to the mixed methods research design. The target population in this study is 107 and used Total Population Sampling to study the 107 respondents. The study used interview guide and self-administered questionnaire for data collection. The quantitative data will be coded and analyzed systematically and presented using figure, percentages and chats. The qualitative data was analyzed according to the emerging themes and the results of both the quantitative and qualitative findings were compared to draw out their significance for the study.

Findings: The study established that social status, lack of awareness and perception that clerical vocation is more prestigious and glamorous than that of brotherhood are some of the factors affecting reduced vocations in brotherhood.

Unique contribution to theory, policy, and practice: The study recommends the need for a rigorous promotion of brotherhood vocations, training of brothers as professionals, uplift the status of brothers and put in place proper discernment of vocations to reduce the high rate of brothers' turnover.

Key Words: Social Status, Clerical congregation, Professional Career Satisfaction, Vocational Motivation and Brotherhood Vocations 


\subsection{INTRODUCTION}

A religious vocation is a special grace that God gives to certain persons, calling them to a life of the evangelical counsels. Sammon (2007) notes that the idea of vocation is central to Christian life. God has created each person with gifts and talents oriented towards specific purposes and a way of life through particular vocational; life commitments. Some are in marriage others are consecrated as religious brothers or sisters while others are ordained as priests in the Church and others live holy lives as single persons. This particular study only focuses on the religious brothers. Champagnat, the founder of Marist Brothers defined a brother as someone predestined for great piety, a very pure life and solid virtue; a soul for whom God's mercy has special plans (Champagnat, 1927). Vocation, when defined as a calling, is traditionally understood as being applied to clergy or other religious groups (Coombs \& Nemeck, 2018). Historically, vocation has been represented as experiencing a vision, a visitation of a divine spirit, and/or hearing God's voice; followed by an initiation into public ministry (Gaunt, 2018). However, recent scholarship on vocation as a calling has defined it more broadly, referring to individuals' choices about how to express the essence of oneself in life and through one's work; that is, work that one is naturally inclined to do and in which one finds personal expression of the self (Lespinay, 2010). Studies on work for the common good underscore the importance of this sense of vocation or calling (Colby \& Damon, 1992; Daloz, Keen, Keen, \& Parks, 1996; Hansen, 1995; Lashley, Neal, Slunt, Berman, \& Hultgren, 1994), and suggest the need to understand more clearly the relationship between who one is as a person, and the commitments one makes to the world. Daloz et al., (1996) argued that social commitment and vocation are closely intertwined, implying that life calling benefits both the individual who experiences it, and those who are impacted by the life of that individual.

The past four decades have seen a decline in the number of Catholic Vocations (Rosangela \& Eliane,2017). Although there are various explanations attributed to this loss of vocations, the most popular one according to Stark and Finke (2000) is that the church has refused to respond to the demands of the new generation of Catholics that are not comfortable with the traditions of the Church that demands sacrifices such as the vows of celibacy, obedience and poverty. According to a survey conducted by National Religious Vocation Conference (2013), students' inability to clear their education loans was denying them a chance to join religious life. The survey also noted that most parents were reluctant in encouraging their children to join religious life. A study carried out by Stark and Finke (2000) established that the history of this decline could be traced at Vatican II Council, which greatly reduced the rewards of religious life while maintaining high costs of vocations. The current study focuses on the Congregation of Holy Cross, which like numerous other congregations is facing a dilemma in terms of attracting and retaining vocations. Moreau founded the Congregation of Holy Cross on March 1, 1837, in Sainte-Croix, which at the time was a small village outside of Le Mans, France. The Congregation of Holy Cross is an apostolic religious congregation composed of two distinct societies of religious brothers and religious priests "bound together in one indivisible brotherhood" (Cleary, 2018). Throughout the history of the Congregation of Holy Cross, its mission has been to share in the Church's mission by working as educators in the faith. In all of its ministries, whether schools, parishes, or other works of missionary outreach and social justice. The Congregation of Holy Cross serves side-by-side with its collaborators through educating hearts and minds and building communities of the coming kingdom. 


\subsection{Statement of the Problem}

Holy Cross has witnessed a sustained decline of vocations since 2000. For instance, in 2000, only one brother made his perpetual vows in the Congregation. According to available statistics, between the year 2000 and 2006 no single brother was accepted into the perpetual vows (Holy Cross, 2008). In 2007, one brother took perpetual vows but left the congregation a few years later. In 2008, there was one brother who made his perpetual profession; and in 2011, another brother also professed his perpetual vows. From 2011 to 2014 only one brother has made a perpetual vow. Between 2016 and 2018, the congregation has had only three perpetually professed brothers (Holy Cross Congregation Directory, 2018). The current study focuses on whether this decline is due to social status, preference for clerical vocation or desire for a professional career. It is in the light of these statistics that this study is being carried out to determine the factors influencing this decline in vocation, specifically within the Holy Cross Congregation in East Africa. Available literature reveals that ability to balance work and personal life, work that is truly enjoyable, security for the future, satisfactory reward and enjoyable collaborators are some of the factors that influence vocational decision (Yankelovich \& Partners, 1998; Finke, 2000). For instance, a study carried out by Finke, 2000 on Catholic religious' vocations noted that young Catholics became far less likely to take up the religious life due to the recognition that vocations entailed a negative cost / benefit ratio. Hence, according to Starke and Finke (2000), vocations will only flourish if the candidate values the benefit more than the costs. These studies were conducted in Americas, Europe, Asia and other parts of Africa and not in East Africa. Similarly, the rewards associated with joining religious life are likely to determine the decision to join, leave or stay in a religious congregation. Thus, the need to carry out this study to fill these gaps by exploring factors influencing decline in vocation with special focus on the Holy Cross Congregation in East Africa.

\subsection{Research Objectives}

i. To explore how consideration for social status influence vocation to brotherhood in the Holy Cross Congregation in East Africa;

ii. To examine how preference to join clerical congregation impacts vocation to brotherhood in the Holy Cross Congregation in East Africa;

iii. To determine how professional career satisfaction influences vocation to brotherhood in the Holy Cross Congregation in East Africa;

iv. To investigate how different motivations influence vocation to brotherhood in the Holy Cross Congregation in East Africa;

v. To identify possible ways of responding to the rate in vocation to brotherhood in Holy Cross Congregation in East Africa

\subsection{THEORETICAL REVIEW}

\subsection{Person Centred Theory of Carl Rogers}

Person Centered Theory was developed by Carl Rogers in the 1940's and advocated for the individual's ability to move towards self-actualization and health when proper and conducive environment is provided. He observed that for a person to 'grow', they need an environment that provides them with genuine love, acceptance and empathy. According to Corey (2011) the person-centered theory was developed from the work of the psychologist Dr. Carl Rogers (19021987). Although initially developed as an approach to psychotherapy, Rogers and his colleagues 
believed that their ideas could be transferred to other areas where people were in relationships such as teaching, management, childcare, patient care and conflict resolution among others. This theory states that human beings have an actualizing tendency of finding fulfilment of their personal potentials, which include sociability, the need to be with other human beings and a desire to know and be known by other people. It also includes being open to experience, being trusting and trustworthy, being curious about the world, being creative and compassionate (Corey, 2011).

Rogers advocates for an environment where a person feel free from threat, both physically and psychologically. This environment could be achieved when being in a relationship with a person who is deeply understanding (emphatic), accepting (having unconditional positive regard) and genuine (congruent) (Crandell, 2009). In this case, the candidates that joins religious life expect to be accorded understanding, provided with unconditional and genuine love for them to be able to grow to the fullest of their potential. In tandem with Rogers who believed that every person could achieve their goals, wishes, and desires in life, and so do religious brothers, upon which one would say that they have reached self-actualization or their fullest potential in life. The brothers have the potential to achieve their desired goals in life if only they are accorded love, care, understanding, education and proper mentorship. What they require is what Rogers advocate for, that is an environment where they can feel loved, cared for, free from threat, both physically and psychologically. The strength of Person Centred Theory is that it has been recognized as helpful in interventions such as couching, counselling, mentoring, social care and teaching (Bachkirova, 2018). It is a powerful tool in ensuring that the victim is put in charge of their lives and expected to turn things round to become fully functioning human beings. Providing an enabling environment which is safe and nurturing enables the person to develop a positive self-worth, positive self-regard, self-trust and ability to have a positive world view.

\subsection{The Model of the Congregation of Holy Cross}

This study is hinged on the charisma of the Congregation of Holy Cross. The Congregation of Holy Cross draws its spirituality from Blessed Basil Moreau who was born in Laigné-en-Belin, in the Diocese of Le Mans, France, on Feb. 11, 1799. In 1821, he was ordained a priest for the Diocese of LeMans. Moreau grew up during the French Revolution turmoil and as a young priest he felt compelled to revitalize a Church devastated by years of civil war. With nearly twothirds of France's clergy and religious exiled or killed, Moreau organized a group of Auxiliary Priests to preach, teach, and bring the message of Christ to those in neglected towns and villages. Moreau was a priest full of the zeal of making God known, loved and served. He openly embraced the mission that Christ had entrusted to the Church. He laid a great emphasis on holiness, as he perceived himself and his members as apostles working on behalf of Christ (Giallanza, 2008). Blessed Moreau called on the priests and brothers of Holy Cross to be "educators in the faith," who with a preferential option for the poor, educate both mind and heart principally in the fields of education, parish and mission (James, 2003).

This distinctive charism and trust in Divine Providence has guided Holy Cross members to found world-renowned institutes of Catholic higher education, parishes across the United States and Mexico, Africa, along with other important ministries on five continents. The Holy Spirit within Blessed Basil Moreau (Founder) offered the congregation of Holy Cross to become educators in the faith. This was purposely to build the Church through responding to the needs of humanity. This role is reiterated in the constitutions of the congregation of Holy Cross as 
follows, "As disciples of Christ, we stand side by side with all people. Like them, we are burdened by the same struggles and beset by the same weaknesses; like them we are made new by the same Lord's love; like them we hope for a world where justice and love prevail. Thus, wherever through its superiors the congregation sends us we go as educators in the faith to those whose lot we share, supporting men and women of grace and good will everywhere in their efforts to form communities of the coming kingdom" (Holy Cross Constitution 2:12).

\subsection{Maslow's Hierarchy of Need Theory}

Similarly, this study is anchored on Maslow's hierarchy of need theory. Maslow theorized that people have five types of needs and that these are activated in a hierarchical manner. This means that these needs are aroused in a specific order from lowest to highest, such that the lowest-order need must be fulfilled before the next order need is triggered and the process continues (Maslow, 1943). In his order of needs, physiological needs are at the bottom of the pyramid and include the lowest order need and most basic. This includes the need to satisfy the fundamental biological drives such as food, air, water and shelter. According to Maslow, every human being needs to afford adequate living conditions. The rationale here is that any hungry person will hardly be able to make much of any contribution to his job. To this end, even as much as brotherhood is led by vows of poverty, chastity and obedience, they need to fulfil their physiological needs (McLeod, 2007). Safety needs occupy the second level of needs. Safety needs are activated after physiological needs are met. They refer to the need for a secure working environment free from any threats or harms. The rationale is that people working in an environment free of harm do their jobs without fear of harm. Social needs represent the third level of needs. They are activated after safety needs are met. Social needs refer to the need to be affiliated. The brothers in the Congregation of Holy Cross in East Africa need to be loved and accepted by other people. Esteem needs represents the fourth level of needs. It includes the need for self-respect and approval of others (Koltko-Rivera, 2006). Finally, self-actualization occupies the last level at the top of the pyramid. This refers to the need to become all that one is capable of being to develop one's fullest potential. The rationale here holds to the point that self-actualized people represent valuable assets to the Congregation of the Holy Cross (Jerome, 2013). 


\subsection{Conceptual Framework}

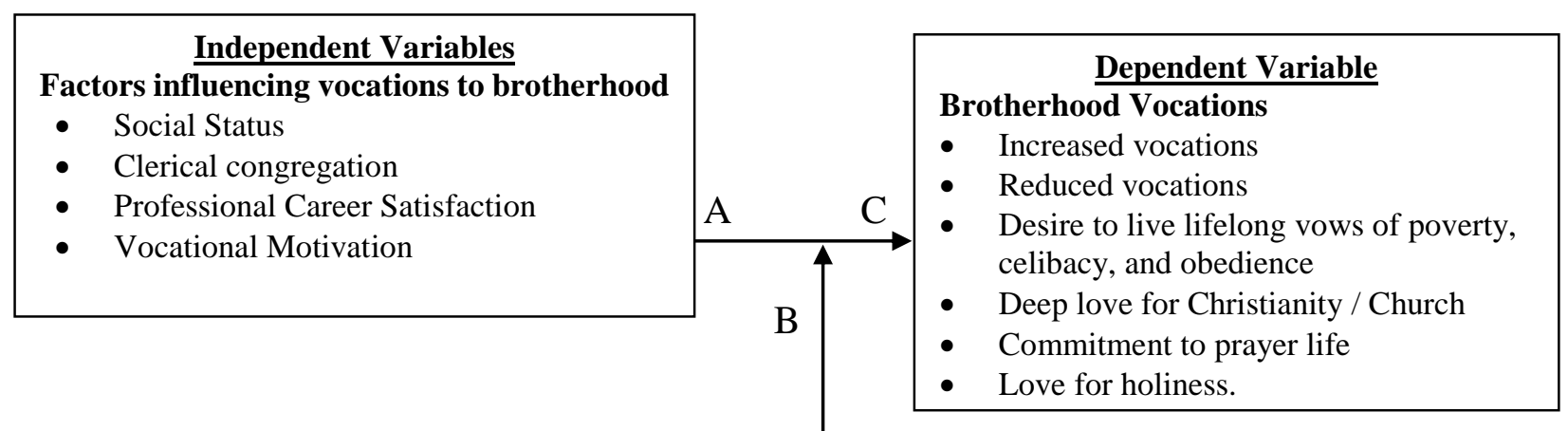

\begin{tabular}{lll}
\hline & \multicolumn{1}{c}{ Intervening Variables } \\
- & Modern Culture of Consumerism/Secularism \\
- & African Cultural Values \\
- & Religiosity Background \\
\hline
\end{tabular}

\subsection{RESEARCH METHODOLOGY}

The study used convergent parallel approach to the mixed methods research design. The target population in this study is 107 and used Total Population Sampling to study the 107 respondents. The study used interview guide and self-administered questionnaire for data collection. The quantitative data will be coded and analyzed systematically and presented using figure, percentages and chats. The qualitative data was analyzed according to the emerging themes and the results of both the quantitative and qualitative findings were compared to draw out their significance for the study.

\subsection{PRESENTATION OF FINDINGS}

The study expected 107 respondents to participate but only 58 were able to participate. This translates to $54 \%$ participation rate, which can be considered sufficient for the study.

\subsection{Influence of Social Status on Vocation to Brotherhood}

This objective had six items that wanted to establish whether social status had an influence on brotherhood vocations. The results of these analyses are presented as follows:

\subsubsection{Pressure from Family}

Table 1: Pressure from family and relations

\begin{tabular}{lccccc}
\hline $\begin{array}{l}\text { Pressure from } \\
\text { Family }\end{array}$ & Priests & Postulants & Novices & $\begin{array}{c}\text { Perpetually } \\
\text { Professed }\end{array}$ & Total \\
\hline Strongly Agree & $0 \%$ & $4(44 \%)$ & $5(19 \%)$ & $1(8 \%)$ & $\mathbf{1 0}$ \\
Agree & $3(27 \%)$ & $0 \%$ & $10(39)$ & $8(67 \%)$ & $\mathbf{2 1}$ \\
Neutral & $0 \%$ & $0 \%$ & $1(4 \%)$ & $0 \%$ & $\mathbf{1}$ \\
Disagree & $4(36 \%)$ & $2(22 \%)$ & $7(27 \%)$ & $3(25 \%)$ & $\mathbf{1 6}$ \\
Strongly Disagree & $4(36 \%)$ & $3(33 \%)$ & $3(11 \%)$ & $0 \%$ & $\mathbf{1 0}$ \\
\hline Total & $\mathbf{1 1 ( 1 0 0 \% )}$ & $\mathbf{9 ( 1 0 0 \% )}$ & $\mathbf{2 6 ( 1 0 0 \% )}$ & $\mathbf{1 2 ( 1 0 0 \% )}$ & $\mathbf{5 8}$ \\
\hline
\end{tabular}


The respondents were asked whether pressure from family and relations is among the major challenges determining the rate of vocations to brotherhood, to which majority $(31,53 \%)$ concurred as shown by3 (27\%) of priests, $4(44 \%)$ of postulants, $15(58 \%)$ of novices and 9 $(75 \%)$ of perpetually professed. Those that refuted that assertion were $45 \%$ of the respondents as shown by $8(72 \%)$ of priests, $5(55 \%)$ of postulants, $10(38 \%)$ of the Novices and $3(25 \%)$ of the perpetually professed respondents. However, 1 (4\%) of the novice respondents were undecided. This implies that pressure from families and relations may discourage potential brothers to join brotherhood. The study recommends that vocational directors should also take time to discuss with the parents or guardians of a candidate about vocations. It also calls for sensitization of the public about the importance of religious vocations.

\subsubsection{African Culture}

The study wanted to find out whether African culture had an influence on the rate of brotherhood vocations. The results of this analysis are presented as follows:

Table 2: Influence of African culture

\begin{tabular}{lccccc}
\hline $\begin{array}{l}\text { The African culture encourages } \\
\text { marriages and therefore does not } \\
\text { approve one joining brotherhood }\end{array}$ & Priests & Postulants & Novices & $\begin{array}{c}\text { Perpetually } \\
\text { Professed }\end{array}$ & Total \\
\hline Strongly Agree & $0 \%$ & $1(11 \%)$ & $4(15 \%)$ & $3(25 \%)$ & $\mathbf{8}$ \\
Agree & $2(18 \%)$ & $3(33 \%)$ & $8(31 \%)$ & $3(25 \%)$ & $\mathbf{1 6}$ \\
Neutral & $8(73 \%)$ & $1(11 \%)$ & $6(23 \%)$ & $4(33 \%)$ & $\mathbf{1 9}$ \\
Disagree & $1(9 \%)$ & $3(33 \%)$ & $5(19 \%)$ & $2(17 \%)$ & $\mathbf{1 1}$ \\
Strongly Disagree & $0 \%$ & $1(11 \%)$ & $3(11 \%)$ & $0 \%$ & $\mathbf{4}$ \\
\hline Total & $\mathbf{1 1 ( 1 0 0 \% )}$ & $\mathbf{9 ( 1 0 0 \% )}$ & $\mathbf{2 6 ( 1 0 0 \% )}$ & $\mathbf{1 2 ( 1 0 0 \% )}$ & $\mathbf{5 8}$ \\
\hline
\end{tabular}

Regarding whether the African culture encourages marriages and therefore does not approve one joining brotherhood, $24(41 \%)$ concurred as evidenced by $2(18 \%)$ of the priests, $4(44 \%)$ of postulants, $12(46 \%)$ of Novices and $6(50 \%)$ of the perpetually professed respondents. This was followed closely by those who were undecided who comprised of $8(73 \%)$ of priests, 1 $(11 \%)$ of postulants, $6(23 \%)$ of novices and $4(33 \%)$ of those perpetually professed. Those who showed disagreement included $1(9 \%)$ of the priests, $444 \%$ of postulants, $8(30 \%)$ of Novices and $2(17 \%)$ of the perpetually professed respondents. The slight majority is an indication that indeed, the African culture does have some negative effect in discouraging Africans from joining brotherhood. There is therefore need to educate people about the importance of religious vocations. 


\subsubsection{Desire to be Rich}

The study wanted to know whether the desire to be rich was impacting on the rate of brotherhood vocations. The results of this analysis are presented on Figure 2.

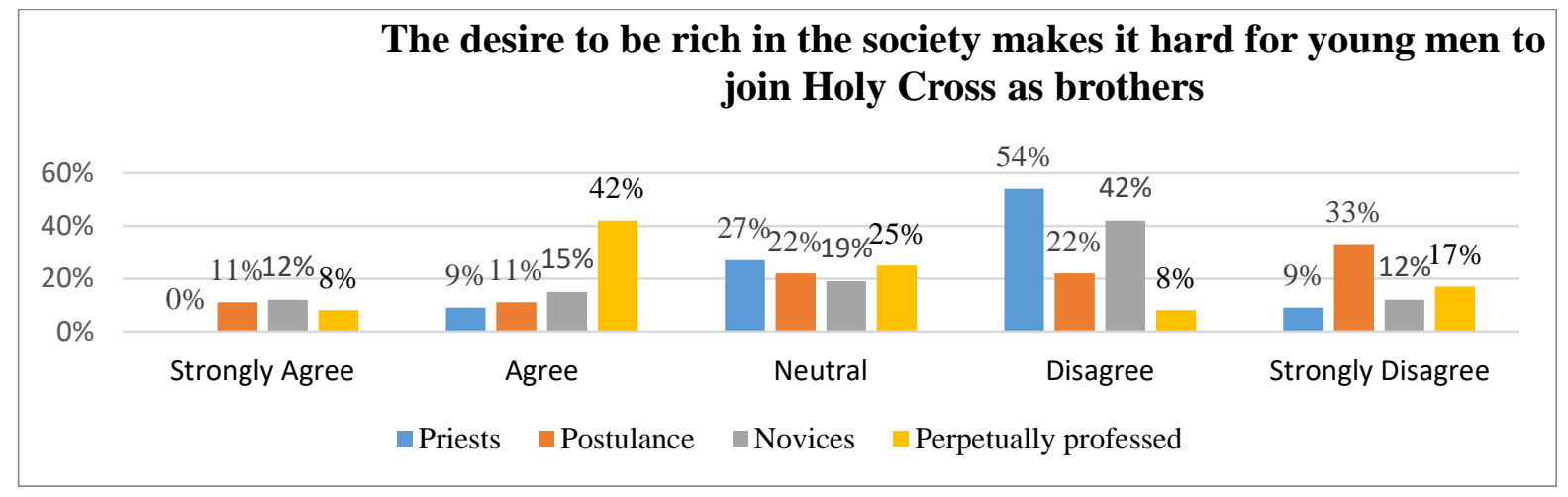

\section{Figure 2: The desire to be rich}

Respondents were asked whether the desire to be rich in the society makes it hard for young men to join Holy Cross as brothers, to which majority showed disagreement as indicated by $63 \%$ of priests, $54 \%$ of the novices, $55 \%$ of the postulants and $25 \%$ of the perpetually professed. Those with neutral views were $27 \%$ of the priests, $12 \%$ of the postulants, $19 \%$ of the novices and $25 \%$ of the perpetually professed. Those who concurred were $9 \%$ of the priests, $22 \%$ of the postulants, $27 \%$ of the novices and $50 \%$ of the perpetually professed. One can therefore conclude that the desire to be rich does not prevent young men from joining Holy Cross as brothers. The study recommends that there is need to educate communities about the dangers of materialism.

\subsubsection{Desire to be respected in the Society}

The following are the results of the analysis on whether the desire to be respected in the society was impacting on the rate of brotherhood vocations.

Table 3: The desire to be respected

\begin{tabular}{lccccc}
\hline $\begin{array}{l}\text { The desire to be respected contributes } \\
\text { to the rate of brotherhood vocations in } \\
\text { the Holy Cross community }\end{array}$ & Priests & Postulants & Novices & $\begin{array}{c}\text { Perpetually } \\
\text { Professed }\end{array}$ & Total \\
\hline Strongly Agree & & & & \\
Agree & $3(27 \%)$ & $5(56 \%)$ & $6(23 \%)$ & $3(25 \%)$ & $\mathbf{1 7}$ \\
Neutral & $5(46 \%)$ & $0 \%$ & $15(58 \%)$ & $6(50 \%)$ & $\mathbf{2 6}$ \\
Disagree & $1(9 \%)$ & $1(11 \%)$ & $1(4 \%)$ & $1(8 \%)$ & $\mathbf{4}$ \\
Strongly Disagree & $2(18 \%)$ & $1(11 \%)$ & $3(11 \%)$ & $2(17 \%)$ & $\mathbf{8}$ \\
\hline Total & $0 \%$ & $2(22 \%)$ & $1(4 \%)$ & $0 \%$ & $\mathbf{3}$ \\
\hline
\end{tabular}

The respondents were asked whether the desire to be respected contributes to the rate of vocations in the Holy Cross, to which majority of the respondents $(43,74 \%)$ concurred. Those that showed agreement included $8(73 \%)$ of priests, $5(56 \%)$ of postulants, $21(81 \%)$ of novices and $9(75 \%)$ of perpetually professed. Those with neutral views included $1(9 \%)$ of priests, 1 $(11 \%)$ of postulants, $1(4 \%)$ of novices and $1(8 \%)$ of perpetually professed. Those with contrary opinion were $2(18 \%)$ of priests, $3(33 \%)$ of postulants, $4(15 \%)$ of novices and $2(17 \%)$ of perpetually professed. From these findings, one can conclude that the desire to be respected in 
the society has a great impact on the rate of vocations in Holy Cross community. This calls for the Holy Cross Community to equalize the status of brothers with that of priests in order to enhance vocations in brotherhood vocations.

\subsubsection{Fulfilment in Religious Life}

The study wanted to know the perception of the respondents regarding fulfilment in religious life and secular life. The results of this analysis are presented as follows:

Table 4: On whether religious life is more fulfilling than secular life

\begin{tabular}{lccccc}
\hline $\begin{array}{l}\text { Religious life is more } \\
\text { fulfilling than secular } \\
\text { life }\end{array}$ & Priests & Postulants & Novices & $\begin{array}{c}\text { Perpetually } \\
\text { Professed }\end{array}$ & Total \\
\hline Strongly Agree & $0 \%$ & $1(11 \%)$ & $1(4 \%)$ & $2(17 \%)$ & $\mathbf{4}$ \\
Agree & $1(9 \%)$ & $2(22 \%)$ & $1(4 \%)$ & $1(8 \%)$ & $\mathbf{5}$ \\
Neutral & $8(73 \%)$ & $3(33 \%)$ & $7(27 \%)$ & $6(50 \%)$ & $\mathbf{2 4}$ \\
Disagree & $1(9 \%)$ & $2(22 \%)$ & $6(23 \%)$ & $2(17 \%)$ & $\mathbf{1 1}$ \\
Strongly Disagree & $1(9 \%)$ & $1(11 \%)$ & $11(42 \%)$ & $1(8 \%)$ & $\mathbf{1 5}$ \\
\hline Total & $\mathbf{1 1 ( 1 0 0 \% )}$ & $\mathbf{9 ( 1 0 0 \% )}$ & $\mathbf{2 6 ( 1 0 0 \% )}$ & $\mathbf{1 2 ( 1 0 0 \% )}$ & $\mathbf{5 8}$ \\
\hline
\end{tabular}

When the respondents were asked whether religious life is more fulfilling than secular life, majority of them showed disagreement as evidenced by $26(45 \%)$ of the respondents against 9 $(16 \%)$ that showed agreement. Those who showed disagreement were $2(18 \%)$ of priests, 3 (33\%) of postulants, 17 (65\%) of Novices and $3(25 \%)$ of the Perpetually Professed respondents. Those who agreed comprised of $1(9 \%)$ of priests, $3(33 \%)$ of Postulants, $2(8 \%)$ of Novices and $3(25 \%)$ of the perpetually professed respondents. However, $24(41 \%)$ had neutral views. Although a slight majority $(26,45 \%)$ seems to indicate that religious life is not more fulfilling than secular life, a substantial number $(24,41 \%)$ was also non-committal. This finding implies that religious life is not necessarily more fulfilling than secular life. The study recommends that, when promotion of vocations is being done, this aspect of having a fulfilling life should be emphasized to potential candidates. The Community should also ensure that those who join are subjected to a fulfilling life.

\subsubsection{Social Status Has No Influence on Brotherhood Vocations}

The study wanted to establish the role of social status in determining the rate of brotherhood vocations. The results of this analysis are presented in Table 5.

Table 5: Social status has no influence on brotherhood vocations

\begin{tabular}{lccccc}
\hline $\begin{array}{l}\text { Social status has no } \\
\text { influence on brotherhood } \\
\text { vocations }\end{array}$ & Priests & Postulants & Novices & $\begin{array}{c}\text { Perpetually } \\
\text { Professed }\end{array}$ & Total \\
\hline Strongly Agree & $0 \%$ & $2(22 \%)$ & $2(8 \%)$ & $1(8 \%)$ & $\mathbf{5}$ \\
Agree & $1(9 \%)$ & $0 \%$ & $4(15 \%)$ & $2(17 \%)$ & $\mathbf{7}$ \\
Neutral & $2(18 \%)$ & $3(33 \%)$ & $2(8 \%)$ & $3(25)$ & $\mathbf{1 0}$ \\
Disagree & $5(45 \%)$ & $2(22 \%)$ & $12(46 \%)$ & $3(2 \%)$ & $\mathbf{2 1}$ \\
Strongly Disagree & $3(17 \%)$ & $2(22 \%)$ & $6(23 \%)$ & $3(2 \%)$ & $\mathbf{2 4}$ \\
\hline Total & $\mathbf{1 1 ( 1 0 0 \% )}$ & $\mathbf{9 ( 1 0 0 \% )}$ & $\mathbf{2 6 ( 1 0 0 \% )}$ & $\mathbf{1 2}(\mathbf{1 0 0 \%})$ & $\mathbf{5 8}$ \\
\hline
\end{tabular}

Respondents were told to respond to the statement that 'Social status has no influence on brotherhood vocations,' to which 45 (78\%) showed disagreement against $12(21 \%)$ that showed agreement. However, $10(17 \%)$ were undecided. Those that disagreed were $8(62 \%)$ of priest 
respondents, 4(44\%) of Postulants, 18(69\%) of Novices and 6(4\%) of the Perpetually Professed respondents. Those that agreed were $1(9 \%)$ of priest respondents, $2(22 \%)$ of Postulants, $6(23 \%)$ of Novices and $3(25 \%)$ of the Perpetually Professed respondents. This finding implies that consideration of social status is of great influence on brotherhood vocations. The study recommends that the status of brotherhood should be improved perhaps to the level of the priesthood.

\subsection{Influence of Clerical Congregation on Vocation to Brotherhood}

The study embarked on establishing the influence of clerical congregation on Brotherhood vocations. The following are the results of the analyses.

\subsubsection{Brothers and Priests are of Equal Status}

Table 6: Brothers and Priests are of Equal Status

\begin{tabular}{|c|c|c|c|c|c|}
\hline $\begin{array}{l}\text { Brothers and Priests are } \\
\text { of Equal Status }\end{array}$ & Priests & Postulants & Novices & $\begin{array}{l}\text { Perpetually } \\
\text { Professed }\end{array}$ & Total \\
\hline Strongly Agree & $0(0 \%)$ & $2(22 \%)$ & $2(8 \%)$ & $4(33 \%)$ & 8 \\
\hline Agree & $4(36 \%)$ & $1(11 \%)$ & $7(27 \%)$ & $2(17 \%)$ & 14 \\
\hline Neutral & $0(0 \%)$ & $3(33 \%)$ & $5(19 \%)$ & $0(0 \%)$ & 8 \\
\hline Disagree & $4(36 \%)$ & $3(33 \%)$ & $7(27 \%)$ & $4(33 \%)$ & 18 \\
\hline Strongly Disagree & $3(27 \%)$ & $1(11 \%)$ & $5(19 \%)$ & $2(17 \%)$ & 11 \\
\hline Total & $11(100 \%)$ & $9(100 \%)$ & $26(100 \%)$ & $12(100 \%)$ & 58 \\
\hline
\end{tabular}

Regarding whether brothers and priests are of equal status, the study shows that majority of the respondents amounting to $29(50 \%)$ were of the opinion that brothers and priests are not of the same status. Those who disagreed were 7(63\%) of priests, $4(44 \%)$ of Postulants, $12(46 \%)$ of Novices, $6(50 \%)$ of the Perpetually Professed respondents. Those with contrary opinion were $22(37 \%)$ represented by $4(36 \%)$ of priest respondents, $3(33 \%)$ of Postulants, $9(35 \%)$ of Novices and $6(50 \%)$ of the Perpetually Professed respondents while 8(13\%) were noncommittal. Based on the majority of the respondents $(29,50 \%)$, this can be interpreted to mean that brothers and priests are not of equal social status. The study recommends that the Holy Cross community should strive to improve the status of brothers to equal or surpass that of priests in order to attract more potential candidates.

\subsubsection{Brotherhood Vocation Is Less Understood}

The study wanted to find out whether Brotherhood Vocation is well understood in the society. The results of this analysis are presented in Table 7. 
Table 7: Brotherhood vocation less understood compared to clerical vocation

\begin{tabular}{|c|c|c|c|c|c|}
\hline $\begin{array}{l}\text { Brotherhood } \\
\text { vocation is less } \\
\text { understood in the } \\
\text { society compared to } \\
\text { clerical vocation }\end{array}$ & Priests & Postulants & Novices & $\begin{array}{l}\text { Perpetually } \\
\text { Professed }\end{array}$ & Total \\
\hline Strongly Agree & $9(82 \%)$ & $6(67 \%)$ & $19(73 \%)$ & $7(58 \%)$ & 41 \\
\hline Agree & $1(9 \%)$ & $2(22 \%)$ & $6(23 \%)$ & $3(25 \%)$ & 12 \\
\hline Neutral & $0(0 \%)$ & $0(0 \%)$ & $0(0 \%)$ & $1(8 \%)$ & 1 \\
\hline Disagree & $1(9 \%)$ & $0(0 \%)$ & $1(4 \%)$ & $0(0 \%)$ & 2 \\
\hline Strongly Disagree & $0(0 \%)$ & $1(11 \%)$ & $0(0 \%)$ & $1(8 \%)$ & 2 \\
\hline Total & $11(100 \%)$ & $9(100 \%)$ & $26(100 \%)$ & $12(100 \%)$ & 58 \\
\hline
\end{tabular}

The analysis on whether brotherhood vocation is less understood in the society compared to clerical vocation, shows that an overwhelming majority of the respondents $(53,91 \%)$ were categorical that brotherhood vocation is less understood in the society compared to clerical vocation. Those with contrary opinion were $4(7 \%)$ while $1(2 \%)$ had neutral views. Based on the majority of the respondents, it is clear that indeed, brotherhood vocation is less understood in the society compared to clerical vocation. The study recommends that more efforts are needed to create awareness in the society about brotherhood vocations.

\subsubsection{Parental Influence}

The study wanted to find out whether parents had any influence on Brotherhood Vocations. The results of this analysis are presented as follows:

Table 7: Parental Influence

\begin{tabular}{lccccc}
\hline $\begin{array}{l}\text { Desire to see their sons as priests } \\
\text { make parents discourage them } \\
\text { from realizing their vocation as } \\
\text { brothers }\end{array}$ & Priests & Postulants & Novices & $\begin{array}{c}\text { Perpetually } \\
\text { Professed }\end{array}$ & Total \\
\hline Strongly Agree & & & & \\
Agree & $2(18 \%)$ & $3(33 \%)$ & $9(35 \%)$ & $3(25 \%)$ & $\mathbf{1 7}$ \\
Neutral & $6(54 \%)$ & $2(22 \%)$ & $14(54 \%)$ & $6(50 \%)$ & $\mathbf{2 8}$ \\
Disagree & $2(18 \%)$ & $1(11 \%)$ & $1(4 \%)$ & $2(17 \%)$ & $\mathbf{6}$ \\
Strongly Disagree & $0(0 \%)$ & $3(33 \%)$ & $9(35 \%)$ & $1(8 \%)$ & $\mathbf{1 3}$ \\
\hline Total & $1(9 \%)$ & $0(0 \%)$ & $0(0 \%)$ & $0(0 \%)$ & $\mathbf{1}$ \\
\hline
\end{tabular}

The respondents were asked whether the desire for parents to see their sons as priests make parents discourage them from realizing their vocation as brothers. Those who concurred were $45(78 \%)$ against $14(24 \%)$ who had contrary opinion while $6(10 \%)$ were non-committal. Those that concurred included $8(72 \%)$ of priest respondents, $5(55 \%)$ of Postulants, $23(89 \%)$ of Novices and $9(75 \%)$ of the Perpetually Professed respondents. Those that refuted were $1(9 \%)$ of priests, 3 (33\%) of Postulants and $9(35 \%)$ of Novices. The result of this analysis implies that parents are influential in determining whether their sons will join brotherhood or not. Hence, more sons are likely to be prevailed upon to join priesthood than brotherhood which is seen as inferior. This also can be construed to mean that priesthood is seen as more respected and adored in the society compared to brotherhood. The study recommends that more promotion of brotherhood vocations is required to sensitize people about the importance of brotherhood vocations and their role in the society. 


\subsubsection{The Status of Priests}

The study wanted to find our whether brothers were attracted to priesthood more than brotherhood due to the perceived respectable status of the priests. The results of this analysis are presented in Table 8 below:

Table 8: The status of priests

\begin{tabular}{|c|c|c|c|c|c|}
\hline $\begin{array}{l}\text { The status of priests is a } \\
\text { factor that led to the rate } \\
\text { in vocation to } \\
\text { brotherhood. }\end{array}$ & Priests & Postulants & Novices & $\begin{array}{c}\text { Perpetually } \\
\text { Professed }\end{array}$ & Total \\
\hline Strongly Agree & $1(9 \%)$ & $1(11 \%)$ & $10(38 \%)$ & $4(33 \%)$ & 16 \\
\hline Agree & $0(0 \%)$ & $4(44 \%)$ & $8(31 \%)$ & $3(25 \%)$ & 15 \\
\hline Neutral & $9(82)$ & $3(33 \%)$ & $3(11 \%)$ & $3(25 \%)$ & 18 \\
\hline Disagree & $0(0 \%)$ & $1(11 \%$ & $3(11 \%)$ & $2(17 \%)$ & 6 \\
\hline Strongly Disagree & $1(9 \%)$ & $0(0 \%)$ & $2(8 \%)$ & $0(0 \%)$ & 3 \\
\hline Total & $11(100 \%)$ & $9(100 \%)$ & $26(100 \%)$ & $12(100 \%)$ & 58 \\
\hline
\end{tabular}

Majority of the respondents amounting to $31(53 \%)$ were of the opinion that the status of priests is a factor that lead to the rate in vocation to brotherhood. Those who concurred were $1(9 \%)$ of priest respondents, $5(55 \%)$ of postulants, $18(69 \%)$ of Novices and $7(58 \%)$ of perpetually professed respondents. This was against $9(15 \%)$ that had contrary opinion. They were represented by $1(9 \%)$ of priests, $1(11 \%)$ of Postulants, 519\%) of Novices and $2((17 \%)$ of perpetually professed respondents. However, 18 (31\%) had neutral opinion. They were represented by $9(82 \%)$ of Priests, $3(33 \%)$ of Postulants, $3(11 \%)$ of Novices and $3(25 \%)$ of Perpetually Professed respondents. This is an indication that most potential brothers weigh between priesthood and brotherhood based on the perceived status of either. Priests are regarded to have a higher status than that of the brothers. This implies that fewer candidates will join brotherhood compared to those joining brothers. The study recommends uplifting of the status of brothers and carrying out of aggressive brotherhood vocation promotions.

\subsubsection{Desire to Be Seen as a Minister of the Sacraments}

The study wanted to find out whether the desire for the brothers to be seen as ministers of the sacraments attracted them more to priesthood than to brotherhood. The results of this analysis are presented as follows:

Table 9: Desire to be seen as a minister of the sacraments

\begin{tabular}{lccccc}
\hline $\begin{array}{l}\text { Desire to be seen as a } \\
\text { minister of the } \\
\text { sacraments leads to low } \\
\text { intakes in brotherhood } \\
\text { vocation }\end{array}$ & Priests & Postulants & Novices & $\begin{array}{c}\text { Perpetually } \\
\text { Professed }\end{array}$ & Total \\
\hline $\begin{array}{l}\text { Strongly Agree } \\
\text { Agree }\end{array}$ & $3(27 \%)$ & $1(11 \%)$ & $7(27 \%)$ & $2(17 \%)$ & $\mathbf{1 3}$ \\
Neutral & $4(36 \%)$ & $2(22 \%)$ & $11(42 \%)$ & $4(33 \%)$ & $\mathbf{2 1}$ \\
$\begin{array}{l}\text { Disagree } \\
\text { Strongly Disagree }\end{array}$ & $2(18 \%)$ & $5(56 \%)$ & $5(19 \%)$ & $3(25 \%)$ & $\mathbf{1 5}$ \\
\hline Total & $1(9 \%)$ & $1(11 \%)$ & $3(12 \%)$ & $2(17 \%$ & $\mathbf{7}$ \\
\hline
\end{tabular}


Majority of the respondents $(34,59 \%)$ were in agreement that the desire to be seen as a minister of the sacraments by potential candidates makes them opt for priesthood and shun brotherhood vocation. Those who concurred included 7 (63\%) of Priests, 3 (33\%) of Postulants, 18 (69\%) of Novices and $6(50 \%)$ of the Perpetually Professed respondents. Those with contrary opinion were $9(16 \%)$ of the respondents while $15(26 \%)$ of the respondents had neutral views. Those with contrary opinion included 2 (18\%) of Priests, 1 (11\%) of Postulants, 3 (12\%) of Novices and $3(25 \%)$. Those with neutral views were $2(18 \%)$ of Priests, 5(56\%) of Postulants, $5(19 \%)$ of Novices and $3(25 \%)$ of Perpetually Professed respondents. Based on the majority of the respondents, the readings imply that priesthood is seen as prestigious and therefore more potential candidates are likely to opt for it and shun brotherhood vocation. The study recommends that those promoting brotherhood vocations need to debark the notion that priests are more important than brothers in the society perhaps because the former are more visible than the latter.

\subsection{Models of Vocation Promotion}

The study wanted to find out whether promotion of vocations by priests attracts more potential brothers to priesthood instead. The results of this analysis are presented as follows:

Table 10: Priests' Role as Vocation Promoter

\begin{tabular}{lccccc}
\hline $\begin{array}{l}\text { Seeing the model of } \\
\text { priests as vocation } \\
\text { promoter influence the } \\
\text { inspiration of candidate } \\
\text { to be a priest }\end{array}$ & Priests & Postulants & Novices & $\begin{array}{c}\text { Perpetually } \\
\text { Professed }\end{array}$ & Total \\
\hline Strongly Agree & & & & \\
Agree & $4(36 \%)$ & $1(11 \%)$ & $3(11 \%)$ & $2(17 \%)$ & $\mathbf{1 0}$ \\
Neutral & $4(36 \%)$ & $2(22 \%)$ & $7(27 \%)$ & $7(58 \%)$ & $\mathbf{2 0}$ \\
Disagree & $2(18 \%)$ & $3(33 \%)$ & $6(23 \%)$ & $3(25 \%)$ & $\mathbf{1 4}$ \\
Strongly Disagree & $0(0 \%)$ & $2(22 \%)$ & $8(31 \%)$ & $0(0 \%)$ & $\mathbf{1 0}$ \\
\hline Total & $1(9 \%)$ & $1(11 \%)$ & $2(8 \%)$ & $0(0 \%)$ & $\mathbf{4}$ \\
\hline
\end{tabular}

The respondents were asked whether seeing the model of priests as vocation promoter influence the inspiration of the candidate to be a priest, to which majority of them at $30(60 \%)$ concurred. The undecided respondents were 14 (24\%) while those with contrary opinion were also 14 (24\%). Those that concurred were $8(72 \%)$ of priests, $3(33 \%)$ of Postulants, $10(38 \%)$ of Novices and $9(75 \%)$ of perpetually professed respondents. Those undecided were $1(18 \%)$ of priests, $3(33 \%)$ of Postulants, $6(23 \%)$ of Novices and $3(25 \%)$ of perpetually professed respondents. Those who had contrary opinion were 1 (9\%) of priests, $3(33 \%)$ of Postulants and $10(39 \%)$ of Novices. This finding implies that it is important to have brothers promoting brotherhood vocations as they are likely to be an inspiration to potential candidates. 


\subsubsection{Professional Career Satisfaction}

This objective endeavoured to establish whether professional career satisfaction affects brotherhood vocations. The results of the analyses of the items of this objective are presented as follows:

\subsubsection{Brotherhood as a Prestigious Profession}

Table 11 Brotherhood as a Prestigious Profession

\begin{tabular}{lccccc}
\hline $\begin{array}{l}\text { Being a brother is not } \\
\text { recognized as a prestigious } \\
\text { profession }\end{array}$ & Priests & Postulants & Novices & $\begin{array}{c}\text { Perpetually } \\
\text { Professed }\end{array}$ & Total \\
\hline Strongly Agree & $5(46 \%)$ & $2(22 \%)$ & $4(15 \%)$ & $3(25 \%)$ & $\mathbf{1 4}$ \\
Agree & $2(18 \%)$ & $3(33 \%)$ & $9(35 \%)$ & $4(33 \%)$ & $\mathbf{1 8}$ \\
Neutral & $3(27 \%)$ & $2(22 \%)$ & $5(19 \%)$ & $3(25 \%)$ & $\mathbf{1 3}$ \\
Disagree & $0(0 \%)$ & $0(0 \%)$ & $8(31 \%)$ & $1(8 \%)$ & $\mathbf{9}$ \\
Strongly Disagree & $1(9 \%)$ & $2(22 \%)$ & $0(0 \%)$ & $1(8 \%)$ & $\mathbf{4}$ \\
\hline Total & $\mathbf{1 1 ( 1 0 0 \% )}$ & $\mathbf{9 ( 1 0 0 \% )}$ & $\mathbf{2 6 ( 1 0 0 \% )}$ & $\mathbf{1 2 ( 1 0 0 \% )}$ & $\mathbf{5 8}$ \\
\hline
\end{tabular}

A majority of the respondents $(32,55 \%)$ were of the opinion that being a brother is not recognized as a prestigious profession against $13(22 \%)$ of the respondents that had contrary opinion. Those in agreement were $7(64 \%), 5(55 \%)$ of postulants, $13(50 \%)$ of Novices and 7 $(58 \%)$ of perpetually professed respondents. Those with neutral views were also $13(22 \%)$ respondents. They were represented by $3(27 \%)$ of Priest respondents, $2(22 \%)$ of Postulants, 5 $(19 \%)$ of Novices and $3(25 \%)$ of Perpetually Professed respondents. Those with contrary opinion were represented by $1(9 \%)$ of priests, $2(22 \%)$ of Postulants, $8(31 \%)$ of Novices and $2(18 \%)$ of Perpetually Professed respondents. Based on the majority of the respondents, it is safe to say that brotherhood is not perceived to be as prestigious as priesthood and therefore, there could be more priesthood vocations than that of brotherhood vocations. This calls for rigorous promotion of brotherhood vocations that seems to be rarely known and also uplifting the status of brothers to make their vocation prestigious as well.

\subsubsection{Training Brothers as Professionals}

The study wanted to establish whether training brothers as professionals would encourage more brotherhood vocations among the Holy Cross Community. The results of this analysis are presented as follows:

\section{Table 12: Training brothers as professionals}

\begin{tabular}{lccccc}
\hline $\begin{array}{l}\text { Training brothers as } \\
\text { professionals would } \\
\text { encourage vocation to be } \\
\text { a brother among the }\end{array}$ & Priests & Postulants & Novices & $\begin{array}{c}\text { Perpetually } \\
\text { Professed }\end{array}$ & Total \\
Holy Cross & & & & \\
\hline Strongly Agree & & & & \\
Agree & $1(9 \%)$ & $5(56 \%)$ & $10(36 \%)$ & $5(42 \%)$ & $\mathbf{2 1}$ \\
Neutral & $7(64 \%)$ & $1(11 \%)$ & $10(36 \%)$ & $3(25 \%)$ & $\mathbf{2 1}$ \\
Disagree & $2(18 \%)$ & $2(22 \%)$ & $4(15 \%)$ & $3(25 \%)$ & $\mathbf{1 1}$ \\
Strongly Disagree & $1(9 \%)$ & $1(11 \%)$ & $2(8 \%)$ & $1(8 \%)$ & $\mathbf{5}$ \\
\hline Total & $0(0 \%)$ & $0(0 \%)$ & $0(0 \%)$ & $0(0 \%)$ & $\mathbf{0}$ \\
\hline
\end{tabular}


There was overwhelming agreement among majority of the respondents $(42,72 \%)$ that training brothers as professionals would encourage vocation to be a brother among the Holy Cross. Those with contrary opinion were $9(15 \%)$ of the respondents while those with neutral opinion were $11(19 \%)$ of the respondents. This implies that it is necessary to train brothers as professionals in order to attract more potential candidates.

\subsubsection{Philosophy and Theological Training for Brothers}

The study wanted to establish whether offering brothers both philosophy and theological training would promote brotherhood vocations in the Holy Cross as presented as follows:

Table 12 Philosophy and Theological training for Brothers

\begin{tabular}{lccccc}
\hline $\begin{array}{l}\text { Offering brother both } \\
\text { philosophy and theological } \\
\text { training would promote } \\
\text { brotherhood vocations in the }\end{array}$ & Priests & Postulants & Novices & $\begin{array}{c}\text { Perpetually } \\
\text { Professed }\end{array}$ & Total \\
Holy Cross & & & & & \\
\hline Strongly Agree & $3(27 \%)$ & $2(22 \%)$ & $2(8 \%)$ & $1(8 \%)$ & $\mathbf{8}$ \\
Agree & $1(9 \%)$ & $0(0 \%)$ & $1(4 \%)$ & $1(8 \%)$ & $\mathbf{3}$ \\
Neutral & $3(27 \%)$ & $2(22 \%)$ & $6(23 \%)$ & $4(33 \%)$ & $\mathbf{1 5}$ \\
Disagree & $2(18 \%)$ & $2(22 \%)$ & $8(31 \%)$ & $4(33 \%)$ & $\mathbf{1 6}$ \\
Strongly Disagree & $2(18 \%)$ & $3(33 \%)$ & $9(35 \%)$ & $2(17 \%)$ & $\mathbf{1 6}$ \\
\hline Total & $\mathbf{1 1 ( 1 0 0 \% )}$ & $\mathbf{9 ( 1 0 0 \% )}$ & $\mathbf{2 6 ( 1 0 0 \% )}$ & $\mathbf{1 2 ( 1 0 0 \% )}$ & $\mathbf{5 8}$ \\
\hline
\end{tabular}

Majority of the respondents $(32,55 \%)$ refuted that offering brothers both philosophy and theological training would promote brotherhood vocations in the Holy Cross. Those with contrary opinion were $15(26 \%)$ while those who supported those assertions were $11(19 \%)$. Among those who did not support the statement were 4 (36\%) of priests, $5(55 \%)$ postulants, 17 $(66 \%)$ of novices and $6(50 \%)$ of perpetually professed. Those with neutral views were $3(27 \%)$ of priests, $2(22 \%)$ of postulants, $6(23 \%)$ of novices and $4(33 \%)$ of perpetually professed. Those that supported the statement were $4(36 \%)$ of priests, $2(22 \%)$ of postulants, $3(125)$ novices and $2(18 \%)$ perpetually professed respondents. The results therefore imply that offering brothers both philosophy and theological training will not necessarily promote vocations to be a brother in the Holy Cross. The study recommends that Holy Cross community should consider offering more studies apart from philosophy and theological training for brothers.

\subsubsection{Reputable Career Path}

The study wanted to establish whether having reputable professionalism would make brothers to stay happily at Holy Cross Community. The results of that analysis are presented as follows:

Table 13: Reputable career path

\begin{tabular}{|c|c|c|c|c|c|}
\hline $\begin{array}{l}\text { A brother in the Holy Cross } \\
\text { would be very happy to spend the } \\
\text { rest of his life as a brother if it } \\
\text { has a reputable career path. }\end{array}$ & Priests & Postulants & Novices & $\begin{array}{c}\text { Perpetually } \\
\text { Professed }\end{array}$ & Total \\
\hline Strongly Agree & $1(9 \%)$ & $3(33 \%)$ & $8(31 \%)$ & $2(17 \%)$ & 14 \\
\hline Agree & $4(36 \%)$ & $1(11 \%)$ & $12(46 \%)$ & $2(17 \%)$ & 19 \\
\hline Neutral & $3(27 \%)$ & $2(22 \%)$ & $3(12 \%)$ & $3(25 \%)$ & 11 \\
\hline Disagree & $3(27 \%)$ & $1(11 \%)$ & $2(8 \%)$ & $5(42 \%)$ & 11 \\
\hline Strongly Disagree & $0(0 \%)$ & $2(22 \%)$ & $1(4 \%)$ & $0(0 \%)$ & 3 \\
\hline Total & $11(100 \%)$ & $9(100 \%)$ & $26(100 \%)$ & $12(100 \%)$ & 58 \\
\hline
\end{tabular}


Majority of the respondents $(33,57 \%)$ were in agreement that a brother in the Holy Cross would be very happy to spend the rest of his life as a brother if it has a reputable career path. Among those who showed agreement were $5(45 \%)$ of priests, 4(44\%) of Postulants, $20(77 \%)$ of Novices and $434 \%$ ) of perpetually professed respondents. Those with contrary opinion were 14(24\%), among which $3(27 \%)$ were priests, $2(22 \%)$ were postulants, $3(12 \%)$ were Novices and $3(25 \%)$ were perpetually professed. Those with neutral opinion were $11(19 \%)$.Majority of the respondents $(33,57 \%)$ were in agreement that a brother in the Holy Cross would be very happy to spend the rest of his life as a brother if it has a reputable career path. Hence, the study shows that a brother in the Holy Cross would be very happy to spend the rest of his life as a brother if it has a reputable career path. This shows the importance of having a reputable career path for the brothers. The study therefore recommends that the community should make brotherhood reputable so as to attract to keep many candidates.

\subsection{Brotherhood and the Need for a Career Path}

The results of the analysis on whether being a brother is a vocation that does not need a career path is presented as follows:

Table 14: Brotherhood and the Need for a Career Path

\begin{tabular}{lccccc}
\hline $\begin{array}{l}\text { Being a brother is a } \\
\text { vocation that does not } \\
\text { need a career path }\end{array}$ & Priests & Postulants & Novices & $\begin{array}{c}\text { Perpetually } \\
\text { Professed }\end{array}$ & Total \\
\hline Strongly Agree & $1(9 \%)$ & $0(0 \%)$ & $2(8 \%)$ & $0(0 \%)$ & $\mathbf{3}$ \\
Agree & $0(0 \%)$ & $2(22 \%)$ & $0(0 \%)$ & $1(8 \%)$ & $\mathbf{3}$ \\
Neutral & $1(9 \%)$ & $2(22 \%)$ & $3(12 \%$ & $1(8 \%)$ & 7 \\
Disagree & $6(55 \%)$ & $0(0 \%)$ & $5(19 \%)$ & $5(42 \%)$ & $\mathbf{1 6}$ \\
Strongly Disagree & $3(27 \%)$ & $5(56 \%)$ & $16(62 \%)$ & $5(42 \%)$ & $\mathbf{2 9}$ \\
\hline Total & $\mathbf{1 1 ( 1 0 0 \% )}$ & $\mathbf{9 ( 1 0 0 \% )}$ & $\mathbf{2 6 ( 1 0 0 \% )}$ & $\mathbf{1 2 ( 1 0 0 \% )}$ & $\mathbf{5 8}$ \\
\hline
\end{tabular}

Majority of the respondents $(45,78 \%)$ disproved that being a brother is a vocation that does not need a career path. They included $9(82 \%)$ of priests, $5(56 \%)$ of postulants, $21(81 \%)$ novices and $10(84 \%)$ of the perpetually professed. Those of the opinion that being a brother is a vocation that does not need a career path were $6(10 \%)$. They included $1(9 \%)$ of priest respondents, 2 $(22 \%)$ postulants, $2(8 \%)$ novices, $1(8 \%)$ of perpetually professed. while those with neutral views were $7(12 \%)$. They included 1 (9\%) of priests, $2(22 \%)$ of postulants, $3(12 \%)$ of novices and $1(8 \%)$ of perpetually professed. These results imply that brothers need a career path. This is a reiteration of the importance placed on the need to have in a place well-defined career path in brotherhood. The study recommends that Holy Cross community should establish well thought-out career paths for those who want to become brothers. 


\subsection{Brothers and Professionalism}

The analysis on whether Brothers are rarely known as professionals are presented as follows:

Table 15: Brothers are rarely known as professionals

\begin{tabular}{|c|c|c|c|c|c|}
\hline $\begin{array}{l}\text { Brothers are rarely } \\
\text { known as professionals }\end{array}$ & Priests & Postulants & Novices & $\begin{array}{c}\text { Perpetually } \\
\text { Professed }\end{array}$ & Total \\
\hline Strongly Agree & $2(18)$ & $2(22 \%)$ & $3(16 \%)$ & $1(8 \%)$ & 8 \\
\hline Agree & $1(9 \%)$ & $1(11 \%)$ & $8(31 \%)$ & $3(25 \%)$ & 13 \\
\hline Neutral & $3(27 \%)$ & $1(11 \%)$ & $10(39 \%)$ & $2(17 \%)$ & 16 \\
\hline Disagree & $2(18 \%)$ & $4(44 \%)$ & $5(19 \%)$ & $4(33 \%)$ & 15 \\
\hline Strongly Disagree & $3(27 \%)$ & $1(11 \%)$ & $0(0 \%)$ & $2(17 \%)$ & 6 \\
\hline Total & $11(100 \%)$ & $9(100 \%)$ & $26(100 \%)$ & $12(100 \%)$ & 58 \\
\hline
\end{tabular}

There was a tie between those who concurred that brothers are rarely known and those who refuted those claims. The study shows that $21(36 \%)$ concurred while $21(36 \%)$ disproved while $16(27 \%)$ had neutral views. This implies that brothers may or may not be known as professionals. This indecision is also reflected by the substantial number of the respondents that was undecided $(16,27 \%)$. The study however, recommends that it would help to let brothers join a profession of their own liking based on their talents and academic prowess.

\subsection{Authentic Vocational Motivation to Be a Brother}

The study wanted to explore whether brothers are driven by authentic vocational calling to join brotherhood. The results of the items of this objective are presented as follows:

\subsubsection{Perseverance}

The results of the analysis on whether Brothers who have sincere vocation will persevere or not are presented as follows:

Table 16: Perseverance

\begin{tabular}{lccccc}
\hline $\begin{array}{l}\text { Brothers who have } \\
\text { sincere vocation will } \\
\text { persevere }\end{array}$ & Priests & Postulants & Novices & $\begin{array}{c}\text { Perpetually } \\
\text { Professed }\end{array}$ & Total \\
\hline Strongly Agree & $8(73 \%)$ & $4(44 \%)$ & $0(0 \%)$ & $8(67 \%)$ & $\mathbf{2 0}$ \\
Agree & $2(18 \%)$ & $3(33 \%)$ & $8(31 \%)$ & $3(25 \%)$ & $\mathbf{1 6}$ \\
Neutral & $0(0 \%)$ & $2(22 \%)$ & $10(39 \%)$ & $1(8 \%)$ & $\mathbf{1 3}$ \\
Disagree & $0(0 \%)$ & $0(0 \%)$ & $5(19 \%)$ & $0(0 \%)$ & $\mathbf{5}$ \\
Strongly Disagree & $1(9 \%)$ & $0(0 \%)$ & $3(16 \%)$ & $0(0 \%)$ & $\mathbf{4}$ \\
\hline Total & $\mathbf{1 1 ( 1 0 0 \% )}$ & $\mathbf{9 ( 1 0 0 \% )}$ & $\mathbf{2 6 ( 1 0 0 \% )}$ & $\mathbf{1 2}(\mathbf{1 0 0} \%)$ & $\mathbf{5 8}$ \\
\hline
\end{tabular}

An overwhelming majority of the respondents $(36,62 \%)$ were in agreement that brothers with sincere vocation will persevere. Those with neutral views were $13(22 \%)$ while those who digressed were $9(16 \%)$. This is a strong indication that those who sincerely want to serve as brothers will persevere despite challenges that may be encountered along the way. The study recommends that the vocation directors should make sure that the candidates undergo strict discernment to ensure that only those who are devoted are admitted.

\subsubsection{Hidden Desire to be a Priest}

The study wanted to establish whether hidden desire to be a priest that are not revealed at the point of admission leads one to give up on an intention to be a brother. The results of this analysis are presented below: 
Table 17: Hidden desire to be a priest but not revealed

\begin{tabular}{lccccc}
\hline $\begin{array}{l}\text { Hidden desire to be a priest that are } \\
\text { not revealed at the point of admission } \\
\text { leads one to give up on an intention } \\
\text { to be a brother }\end{array}$ & Priests & Postulants & Novices & $\begin{array}{c}\text { Perpetually } \\
\text { Professed }\end{array}$ & Total \\
\hline Strongly Agree & $1(9 \%)$ & $2(22 \%)$ & $6(23 \%)$ & $3(25 \%)$ & $\mathbf{1 2}$ \\
Agree & $1(9 \%)$ & $3(33 \%)$ & $8(31 \%)$ & $3(25 \%)$ & $\mathbf{1 5}$ \\
Neutral & $3(27 \%)$ & $2(22 \%)$ & $5(19 \%)$ & $3(25 \%)$ & $\mathbf{1 3}$ \\
Disagree & $2(18 \%)$ & $1(11 \%)$ & $6(23 \%)$ & $2(17 \%$ & $\mathbf{1 1}$ \\
Strongly Disagree & $4(36 \%)$ & $1(11 \%)$ & $1(4 \%)$ & $1(8 \%)$ & $\mathbf{7}$ \\
\hline Total & $\mathbf{1 1 ( 1 0 0 \% )}$ & $\mathbf{9 ( 1 0 0 \% )}$ & $\mathbf{2 6 ( 1 0 0 \% )}$ & $\mathbf{1 2 ( 1 0 0 \% )}$ & $\mathbf{5 8}$ \\
\hline
\end{tabular}

A slight majority of the respondents $(28,48 \%)$ were of the opinion that hidden desire to be a priest that are not revealed at the point of admission leads one to give up on the intention to be a brother. Those with neutral views were 13 (22\%) while those with contrary opinion were 18 (31\%). The finding implies that candidates with hidden desires may not endure the challenges of being a brother. The study recommends for strict discernment of vocations to weed out undesirable candidates who may be having hidden intentions.

\subsubsection{Authentic Calling}

The analysis results of whether when a candidate does not have authentic calling to be a brother, it can blind them from realizing the blessing of being a brother are presented as follows:

Table 18: Authentic Calling

\begin{tabular}{lccccc}
\hline $\begin{array}{l}\text { When a candidate does not have authentic } \\
\text { calling to be a brother, it can blind them } \\
\text { from realizing the blessing of being a } \\
\text { brother. }\end{array}$ & Priests & Postulants & Novices & $\begin{array}{c}\text { Perpetually } \\
\text { Professed }\end{array}$ & $\begin{array}{c}\text { Total } \\
\text { Strongly Agree }\end{array}$ \\
Agree & $2(18 \%)$ & $4(44 \%)$ & $5(19 \%)$ & $3(25 \%)$ & $\mathbf{1 4}$ \\
Neutral & $2(18 \%)$ & $2(22 \%)$ & $17(65 \%)$ & $5(42 \%)$ & $\mathbf{2 6}$ \\
Disagree & $3(27 \%)$ & $2(22 \%)$ & $2(8 \%)$ & $4(33 \%)$ & $\mathbf{1 1}$ \\
Strongly Disagree & $4(36 \%)$ & $0(0 \%)$ & $1(4 \%)$ & $0(0 \%)$ & $\mathbf{5}$ \\
\hline Total & $0(0 \%)$ & $1(11 \%)$ & $1(4 \%)$ & $0(0 \%)$ & $\mathbf{2}$ \\
\hline
\end{tabular}

Majority of the respondents $(40,69 \%)$ were in agreement that when a candidate does not have authentic calling to be a brother, it can blind them from realizing the blessing of being a brother. However,7(12\%) of the respondents had contrary opinion while $15 \%$ of brother respondents had neutral views. This is a strong indication that when a candidate does not have authentic calling to be a brother, it can blind them from realizing the blessing of being a brother. The study recommends that the vocations director should endeavour to scrutinize the candidates to brotherhood to ensure that only those with authentic calling are admitted.

\subsubsection{Brotherhood Life is Perceived Easy from Outside}

The result of the analysis on whether Brotherhood life is perceived to be easy from the outside are presented as follows: 
Table 19: Brotherhood life is perceived to be easy from the outside

\begin{tabular}{lccccc}
\hline $\begin{array}{l}\text { Brotherhood life is perceived to be easy } \\
\text { from the outside }\end{array}$ & Priests & Postulants & Novices & $\begin{array}{c}\text { Perpetually } \\
\text { Professed }\end{array}$ & Total \\
\hline Strongly Agree & $1(9 \%)$ & $2(22 \%)$ & $5(19 \%)$ & $0(0 \%)$ & 8 \\
Agree & $4(36 \%)$ & $4(44 \%)$ & $9(35 \%)$ & $6(50 \%)$ & 23 \\
Neutral & $6(55 \%)$ & $1(11 \%)$ & $5(19 \%)$ & $3(25 \%)$ & 15 \\
Disagree & $0(0 \%)$ & $1(11 \%)$ & $4(15 \%)$ & $2(17 \%)$ & 7 \\
Strongly Disagree & $0(0 \%)$ & $1(11 \%)$ & $3(12 \%)$ & $1(8 \%)$ & 5 \\
\hline Total & $\mathbf{1 1 ( 1 0 0 \% )}$ & $\mathbf{9 ( 1 0 0 \% )}$ & $\mathbf{2 6 ( 1 0 0 \% )}$ & $\mathbf{1 2 ( 1 0 0 \% )}$ & $\mathbf{5 8}$ \\
\hline
\end{tabular}

The analysis shows that majority of the respondents $31(53 \%)$ were of the opinion that brotherhood life is perceived to be easy from the outside. Those with neutral opinion were 15 $(26 \%)$. Those that showed disagreement were $12(21 \%)$. This shows that, it is likely that potential candidates perceive brotherhood life more glamorous than what it actually is. This would also imply that upon joining, they may not last after finding the reality of brotherhood life. The study recommends proper discernment to weed out those with different perceptions.

\subsubsection{Hypocrisy Detection among Potential Candidates}

The study wanted to find out whether hypocrisy among potential candidates in not easy to detect during the discernment exercise. The results of this analysis are presented as follows:

Table 20: Hypocrisy Detection among Potential Candidates

\begin{tabular}{|c|c|c|c|c|c|}
\hline $\begin{array}{l}\text { Hypocrisy among potential } \\
\text { candidates in not easy to detect } \\
\text { during the discernment exercise }\end{array}$ & Priests & Postulants & Novices & $\begin{array}{c}\text { Perpetually } \\
\text { Professed }\end{array}$ & Total \\
\hline Strongly Agree & $0(0 \%)$ & $2(22 \%)$ & $7(27 \%)$ & $2(17 \%)$ & 11 \\
\hline Agree & $4(36 \%)$ & $1(11 \%)$ & $6(23 \%)$ & $2(17 \%)$ & 13 \\
\hline Neutral & $4(36 \%)$ & $3(33 \%)$ & $9(35 \%)$ & $5(42 \%)$ & 21 \\
\hline Disagree & $0(0 \%)$ & $0(0 \%)$ & $2(7 \%)$ & $3(25 \%)$ & 5 \\
\hline Strongly Disagree & $3(27 \%)$ & $3(33 \%)$ & $2(7 \%)$ & $0(0 \%)$ & 8 \\
\hline Total & $11(100 \%)$ & $9(100 \%)$ & $26(100 \%)$ & $12(100 \%)$ & 58 \\
\hline
\end{tabular}

Regarding whether hypocrisy among potential candidates in not easy to detect during the discernment exercise, a slight majority of the respondents amounting to 24 (41\%) concurred while $21(36 \%)$ had neutral views. Those with contrary opinion were $13(22 \%)$.Although a slight majority noted that hypocrisy among potential candidates is not easy to detect during the discernment exercise, a substantial number $(21$ (36\%) had neutral views which implies they did not know. Generally, the readings however suggest that undesirable candidates are still likely to find their way into the brotherhood vocation. This call for thorough discernment of vocations before one is admitted into brotherhood congregation. 


\subsection{Benefits of Brotherhood Vocation}

Regarding whether Brotherhood vocation offers less benefit to most potential candidates, the following are the results of this analysis:

Table 21: Brotherhood vocation offers less benefit to most potential candidates

\begin{tabular}{lccccc}
\hline $\begin{array}{l}\text { Brotherhood vocation offers less benefit } \\
\text { to most potential candidates }\end{array}$ & Priests & Postulants & Novices & $\begin{array}{c}\text { Perpetually } \\
\text { Professed }\end{array}$ & $\begin{array}{c}\text { Total } \\
\text { Strongly Agree }\end{array}$ \\
Agree & $0(0 \%)$ & $1(11 \%)$ & $3(12 \%)$ & $3(25 \%)$ & 7 \\
Neutral & $0(0 \%)$ & $1(11 \%)$ & $0(0 \%)$ & $3(25 \%)$ & 4 \\
Disagree & $1(9 \%)$ & $2(22 \%)$ & $9(35 \%)$ & $0(0 \%)$ & 12 \\
Strongly Disagree & $5(46 \%)$ & $3(33 \%)$ & $8(31 \%)$ & $3(25 \%)$ & 19 \\
Total & $5(46 \%)$ & $2(22 \%)$ & $6(23 \%)$ & $3(25 \%)$ & 16 \\
\hline
\end{tabular}

Majority of the respondents $(35,60 \%)$ were of the opinion that brotherhood vocation does not offer less benefit to most potential candidates. Among those that rejected were $10(92 \%)$ of priests, $5(55 \%)$ of postulants, $14(54 \%)$ of novices and $6(50 \%)$ of the perpetually professed. Those with neutral views were $12(21 \%)$ while those who thought it offers less benefit were 11 $(19 \%)$.Those that opined that brotherhood offers less benefit to most potential candidates were $2(22 \%)$ of postulants, $3(12 \%)$ of novices and $6(50 \%)$ of perpetually professed. The results of this analysis can be interpreted to mean that brotherhood vocation offers many benefits to the candidates. The study recommends that there is need to highlight these benefits to potential candidates to help them make an informed choice.

\subsection{Other Factors Related to Discernment of Authentic Vocation}

The respondents were asked to indicate other factors related to discernment of authentic vocation that could influence the vocation to be a brother among the Holy Cross. The opportunity to pursue higher studies was mentioned where some candidates feel that they may not be able to finance their own studies. It was also suggested that the superior should allow brothers to pursue careers of their choice. It was also suggested that the methods employed by finally professed brothers in their discernment journey should be introduced to those still in formation. The involvement of a brother during formation stages was recommended to make sure that the candidates own and embrace the process. It was suggested that efforts should be made to ensure that brothers and priests are treated equally and avoid a situation where brothers are seen as inferior to priests. For instance, the name given to brothers, 'lay religious' instead of 'religious brothers' is a sign of marginalization or negative stereotyping. It was also noted that there is a wrong notion that there are no stringent measures in joining brotherhood as it is with priesthood. There was also suggestion that studying with a priest candidate may discourage one to be a brother as the society is not familiar with brotherhood vocation compared with priesthood.

\subsection{Mechanisms to Discern and Promote Vocation to Be a Brother}

Several suggestions were given on what should be done to promote brotherhood vocations into Holy Cross Congregation. For instance, it was suggested that candidates should be given equal opportunities during admission into the Congregation. It also emerged that the new candidate should be given a brother to journey with him in terms of spiritual direction. Some suggested that there should be a 'deep talk' about the brotherhood vocation in formation classes. The 
course and the formation house should be separated. It was suggested that the public should be sensitized about brotherhood vocation in the entire East African region. The public should also be sensitized about what brothers do by exposing them to the society. Some suggested that brothers should be allowed to administer sacraments. A special vocational director for brothers' vocation should be appointed in addition to a full time brother to be in charge of promoting vocations. There were also suggestions to give brothers a chance to reside in parishes so as to change people's perception that brothers are less privileged. At some point, it was suggested that brother candidates should have separate joint program to nurture them as brothers and increase their knowledge on brotherhood. It was suggested that Holy Cross Community should find ways of increasing vocations to brotherhood by giving them more incentives. They should make strategies to help brothers appreciate their own vocation as a unique call. There should be proper teaching on vows for brothers.

\subsection{Suggestions for Brothers to Live a Fulfilled and Joyful Life in their Vocation}

The respondents were asked to give recommendations on what should be done to help Holy Cross brothers live a fulfilled and joyful life. It was suggested that the Community should help the brothers pursue their dreams. They should also distribute them equally to work as administrators in the different houses or institutions. The brothers should be treated equally as priests are treated and even try to balance the recruitment process and offer equal services to brothers and priests. The Congregation should live to its motto of, "Ave Crux, Spes Unica- Hail the Cross our only Hope." It should encourage community life and show the positive side of brotherhood vocation. It should recognize and respect their presence in a more realistic way as well as dialogue with them in choosing their educational path so as to be fulfilled in their vocation as well as enjoy it. Further, it was suggested that the Congregation should promote a healthy community and prayer life in Holy cross while formation should have an emphasis on teamwork and value for unity as intended by the founder, Blessed Basil Moreau. They should empower brothers through education to prepare them for leadership and managerial roles in schools and other projects. They should encourage brothers to wear their religious habits on regular basis so that people can recognize them.

\subsection{CONCLUSION}

The study concludes that social status is an important consideration by potential candidates to join brotherhood noting that brotherhood vocation is less understood in the society compared to clerical vocation. More potential candidates are therefore likely to prefer joining priesthood which is perceived to be more prestigious and glamorous than that of brotherhood. The study concludes that there is need for a rigorous promotion of brotherhood vocations, train brothers as professionals, and have a well-defined career path that would lead to a specific profession. It was suggested that it would help to properly discern those with authentic calling to reduce the high rate of brothers' turnover. It was also suggested that the superior should allow brothers to pursue careers of their choice and involve a brother during formation stages to make sure that the candidates own and embrace the process. Giving equal opportunities to brothers and priests during admission into the Congregation would help reduce the notion that clerical vocation is more prestigious. 


\subsection{RECOMMENDATIONS}

The study recommends that the stakeholders in the Holy Cross Congregation especially in East Africa should work in collaboration to address the problem of dwindling brotherhood vocations. The study recommends that management of Holy Cross Congregation should strive to carryout rigorous promotions to popularize brotherhood vocations; The management of the Congregation should embrace equality between brothers and priests: The management of the Congregation should establish well defined career paths that lead to a specific profession.; The management of the Holy Cross Congregation should allow Brothers to pursue careers of their choice based on their talents; The management of the Holy Cross Congregation should carryout out stringent discernment exercises to identify those with authentic calling to reduce the high rate of brothers' turnover; Brothers should be involved during formation stages to make sure that the candidates own and embrace the process; Priests and brothers should be given equal opportunities and criteria during admission into the Congregation to reduce the notion that clerical vocation is more prestigious.

\section{ACKNOWLEDGEMENT}

I thank the almighty God for providing me with health, which enabled me to carry out my studies up to this stage without interference. I also acknowledge the assistance and guidance from my supervisor Rev. Dr. Fredrick Omollo and Rev. Dr. Remigius Ikpe. Special thanks go to Holy Cross District Superior and his Council who enriched my academic life and for their understanding and support.

\section{REFERENCES}

Allen, D. (1999). "Desire to finish college: An empirical link between motivation and persistence. Research in Higher Education 40, 446-485.

Bachkirova, T. (2018). The limits and possibilities of a person-centered approach in coaching through the lens of adult development theories. Philosophy of Coaching: An International Journal, 3(1), 6-22.

Champagnat, M. (1927). Listen to the words of your father. Opinions, conferences, sayings and instructions of Marcellin Champagnat.

Cleary, W. (2018). Spiritan Life and Mission Since Vatican II. Wipf and Stock Publishers.

Colby, A., \& Damon, W. (1992). Some do care: Contemporary lives of moral commitment. New York: Free Press.

Coombs, M.T., \&Nemeck, F.K. (2018). Discerning vocations to the apostolic life, the comparative life and the eremitic life. La Verge: Wipf and Stock Publishers.

Daloz, L. A., Keen, C. H., Keen, J. P., \& Parks, S. D. (1996). Common fire: Leading lives commitment in a complex world. Boston: Beacon Press.

Ferre, J.M. (2015). The religious brother: One way to live the brotherhood of Jesus. Sal Terrae: Marist Brothers.

Gaunt, T.P. (2018). Pathways to religious life. New York: Oxford University Press.

Giallanza, J. (2008). The Seven Sorrows of Mary: A Meditative Guide, Indiana: Ave Maria Press. 
Hoge, D. R., \& Wenger, J. E. (2003). Changes from Vatican II to the Turn of the New Century: Evolving Visions of the Priesthood. Collegeville, MN: Liturgical Press.

Jerome, N. (2013). Application of the Maslow's hierarchy of need theory; impacts and implications on organizational culture, human resource and employee's performance. International Journal of Business and Management Invention, 2(3), 39-45.

Koltko-Rivera, M. E. (2006). Rediscovering the later version of Maslow's hierarchy of needs: Self-transcendence and opportunities for theory, research, and unification. Review of general psychology, 10(4), 302.

Lespinay, G. (2010). Vocations and their formation today. Formation in the religious life call, discernment, adaptation. New York : St. Pauls.

Maslow, A. H. (1943). A theory of human motivation. Psychological review, 50(4), 370.

McLeod, S. (2007). Maslow's hierarchy of needs. Simply Psychology, 1.

National Religious Vocation Conference (2013). Vocations to religious life fact sheet. Chicago, Illinois: NRVC.

Paulines Publication Africa (1995). The Catechism of the Catholic Church. Nairobi: Paulines Publication Africa.

Rosangela, C., \& Eliane, S. F. (2017). Attraction and retention of people for religious life in Catholic religious institutions: the importance of institutional features. Cadernos Ebape.br, 15, 1, 152-168.

Sammon, S.D. (2007). Water from the rock: Marist spirituality flowing in the tradition of Marcelin Champagnat. Rome: Marist Brothers of the Schools.

Stark, R., \& Finke, R. (2000). Catholic religious vocations decline and revival. Review for Religious Research, 42(2), 125-145.

Verdieck, M. J., Shields, J. J., \& Hoge, D. R. (1988). Role of commitment process revisited: American Catholic priests 1970 and 1985. Journal for the Scientific Study of Religion, 27, 524-535.

Wahba, M. A., \& Bridwell, L. G. (1976). Maslow reconsidered: A review of research on the need hierarchy theory. Organizational behavior and human performance, 15(2), 212240.

Washington, DC: Seminary Dept. of the National Catholic Educational Association.

Weisgerber, C. A. (1969). Psychological Assessment of Candidates for a Religious Order. Chicago: Loyola University Press.

Weissman, R. F. (2004). From Brotherhood to Congregation: Confraternital Ritual between Renaissance and Catholic Reformation. Riti e ritualinellesocietàmedievali, 77-94.

Winch, C. (2012). Dimensions of expertise: A conceptual exploration of vocational knowledge. London: Continuum.

Yankelovich Partners (1998). Workers around the world share similar attitudes toward jobs. Houston Business Journal, 29, 39-43. 